\title{
Mimicry in Achebe's Arrow of God
}

\section{Sreejith.S}

Assistant Professor, Saras wathi College of Arts and Science, Vilappil, Thiruvananthapuram, India

\begin{abstract}
The paper is an attempt to study Chinua Achebe's Arrow of God through the lens ofHomi K. Bhabha's concept of 'mimicry.'African Trilogy is a significant picture of African people and the history of how they are lured into a new culture. We see in the trilogy an evolution of mimic men - how the native man evolves into an imitator. There are a lot of representations of mimic men available in the trilogy and they can be categorized into various phases of evolution of "mimic man" according to their ambivalence and hybridity level of their contemporary culture and society.

The paper concentrates mainly on the characters of Arrow of God like Oduche and Unachukwu as they represent the universal condition and behaviour of mimic men.
\end{abstract}

Keywords-Mimicry, Ambivalence.

\section{INTRODUCTION}

Mimicry is the art of mimicking somebody or something. Bhabha starts his essay "Of Mimicry and Man: The Ambivalence of Colonial Discourse" by quoting a few lines from "The Line and Light" by Jacques Lacan:

Mimicry reveals something in so far as it is distinct from what might be called an itself that is behind. The effect of mimicry is camouflage ... It is not a question of harmonizing with the background, but against a mottled background, of becoming mottled - exactly like the technique of camouflage practiced in human warfare. (125)

Bhabha borrowed the concept of "mimicry" from Lacan. The colonized themselves become mottled as they wilfully harmonize with the mottled background of the colonizer.

For Bhabha "colonial mimicry is the desire for a reformed, recognizable Other, as a subject of difference that is almost the same, but not quite" (126). Mimicry thus can be seen a practice encouraged by colonizers in an attempt to create an identity for the colonized.

The cultural domination of colonizer led the colonized to look at themselves as inferior. The westerners, especially the British, were successful in establishing themselves as the civilized, educated, reformed and disciplined category. By using their religion and education as tools for colonizing they indeed forced the colonized to accept their inferiority. Made to judge their own culture, the colonized too accepts their cultural lowliness. As the native culture is destroyed by the colonizer they have no option but to follow the western culture and norms.

When colonial discourse encourages the colonized subject to 'mimic' the colonizer, by adopting the colonizer's cultural habits, assumptions, institutions and values, the result is never a simple reproduction of those traits. Rather, the result is a "blurred copy" of the colonizer that can be quite threatening. This is because mimicry is never very far from mockery, since it can appear to parody whatever it mimics. The real identity of the native is destroyed through the process of imitation and leaves the person to an ambivalent state of utter confusion. Thus "the discourse of mimicry is constructed around an ambivalence" (126).

Achebe's writings are plenty with examples of colonial mimicry. In the first book of "African Trilogy"Things Fall Apart we can find how Christianity is introduced in Nigeria. In the third book Arrow of God Achebe presents a bunch of first category of mimic men. The protagonist's son Oduche and the first convert Moses Unachukwu are the best examples and therefore African Trilogy is a perfect space to employ Bhabha's concepts of Mimicry.

\section{DISCUSSION}

Mimicry in colonial and postcolonial literature is seen when members of a colonized society imitate the language, dress, politics, or cultural attitude of their colonizers. The concept of mimicry was developed by Homi K Bhabha. Bhabha's analysis of mimicry in his essay 'Of Mimicry and Man' is largely based on the Lacanian vision of mimicry as camouflage resulting in colonial ambivalence. He sees the colonizer as a snake in the grass who, speaks in "a tongue that is forked," and produces a mimetic representation that "... emerges as one of the most elusive and effective strategies of colonial power and knowledge"(Bhabha 122).

Things Fall Apart (1958) and Arrow of God (1964) - both the works depict the struggle of Igbo society against all the odds with a kind of fear of the loss of their autonomy. The first one is actually pre-colonial work, whereas the second one falls in the colonial period. No 
Longer at Ease is actually pre-independence work. "African Trilogy" covers the Nigerian cultural history of almost eight decades from 1870s to 1950s. According to the time, period and level of hybridity we can classify the mimic man into two phases. Both the phases can be subdivided into corresponding groups for the convenience of study. The first phase consists of men of pre-colonial and post-colonial Nigeria. The second phase includes preindependent Nigerians. The first group of the first phase of mimic men were mostly interpreters, servants and stewards. The second group belongs to the coverts who were given missionary education. The second phase belongs to the second and third generation of the Christian converts. This phase includes all the men who follows Christianity and who are part of the hybrid culture. The evolution and traits of mimic men are most evident in Arrow of God.

In Arrow of God through the character Oduche we can find in the background of the story of Ezeulu, the development of a mimic man. There are lot of mimic men in the novel but Oduche is the most important as he is more connected to Ezeulu, the protagonist and his ambivalence. Oduche was initiated to follow Christianity by his ambivalent father. Oduche was indeed compelled by Ezeulu to accept the Church. Most of the natives got puzzled by Ezeulu's decision to send Oduche to follow the new religion. His mother Ugoye, "was not happy that her son should be chosen for sacrifice to the white man" (46). Oduche was at first bewildered to enter the Church. But his reluctance or bewilderment "was removed as soon as he began to go to church. He found that he could learn very quickly and he began to think the day when he could speak the language of white man..." (46)For every mimic man it is a dream to master the language of his coloniser. But as Bhabha points out: "mimicry.... not bring equality." We feel pity when we see him learning English alphabets. "His lips moved silently as he spelt out and formed the first words of the reader: a $b$ a aba..." (191)

Oduche is not at all ambivalent like many other mimic men we see in the novel. It is not the conflict between the two religions or cultures that disturb the peace of his mind, but the ambivalent needs of his father. However, we see Oduche preferring the white man's life style over the native culture. One incident that shows his change as a mimic man is when he did not want to participate in the Afo day and help his siblings. He informs his father with a little pride: "I am one of those they have chosen to go to Okperi tomorrow and bring the loads of our new teacher" (13).As a learner of the new religion Oduche "made very good progress and was popular with his teacher and members of the church. He was younger than most other converts, being only fifteen or sixteen. The teacher, Mr. Molokwu, expected great things of him and was preparing him of baptism..." (46) $\mathrm{He}$ becomes so confident and bold to challenge even Unachukwu. Though Unachukwu is the first person in Umuaro to convert into Christianity he shows a great amount of ambivalence. When he rebukes the teacher Mr. Goodcountry by pointing out that Christianity do not ask a convert to hurt a sacred python Oduche stands up and asks: "Is it not true that the Bible does not ask us to kill the serpent. Did not God tell Adam to crush its head after it had deceived his wife?" (49) And he then catches a python and locks it up in a box and this shows that the native religion is no longer a concern for him. He is least concerned about the prestige of his father as the Chief Priest of Ulu when he did that abomination. The box he used to lock up is also of significance. "Only people of the church had such boxes..." (43) and it is there for a metaphor of Christianity as a tool for colonisation.

Ezeulu actually wanted Oduche to be his "eyes and ears" at the church. But the same Ezeulu and his kinsmen witness the rapid change that was happening to Oduche. He was developing into a mimic man and his growth was incontrollable for Ezeulu. He became so unyielding to the native customs when he refused to go and attend the sacrifices after the marriage of his brother. He did not want to "offend the Catechist who preached against sacrifices" (117). Ironically Ezeulu too was not able to attend the sacrifice as the native customs prevented him from participating the sacrifices.

Oduche can be compared with Nwoye of Things Fall Apart. Both of them belongs to the second phase of colonial mimicry. Both of them share some qualities that are scorned by the patriarchal norms of the native society. Both Nwoye and Oduche are weak and sentimental. Oduche mercilessly beats his sister-in-law Ojiugu when he finds her whispering about the lock of python incident. $\mathrm{He}$ cries whenever his father scolds him. In the last chapter of the novel when Ezeulu scolds Oduche for destroying his dreams we see how "Oduche went at the brink of tears" (221).

From the story of Nwoye and Oduche, we can conclude that those who are first attracted by the new religion are those who are despised by the native norms or those who despise the native norms. Nwoye is confused about his own culture's customs. He finds some aspects of it to be wrong. One such example is when someone gives birth to twins and they are forced to kill them, which is something he considers to be cruel. When he learns that the new religion is more compassionate towards twins being born he becomes curious: "Nwoye passed and repassed the little red-earth and thatch building without summoning enough courage to enter" (No Longer at Ease 110). He is ambivalent, he wants to know the message 
and context of the religion but he struggles with his emotions whether to be a part of the new church or not.

Oduche indeed destroyed the selfish hopes of his pushy father. Ezeulu wanted his son to become a sort of a "menace." Menace according to Bhabha is a form of anticolonial resistance. 'Mimicry' is always marked by “a difference that is almost nothing but not quite- to menace - a difference that is almost total but not quite" (131).Ezeu lu says to Oduche:

When I was in Okperi I saw a young white man who was able to write his book with the left hand. From his actions I could see that he had very little sense. But he had power; he could see shout in my face; he could do what he liked. Why? Because he could write with his left hand.... I want you learn and master this man's knowledge so much that if you are suddenly woken up from sleep and asked what it is you will reply. You must learn it until you can write it with your left hand" (189-190).

All the encouragement of Ezeulu was alienating Oduche from him and finally Oduche become too inaccessible. Oduche admired the ones like Mr. Goodcountry, Mr. Holt and Mr. Molokwu who totally scorned the native Ibo traditions and disliked the Unachukwu who still admired the Ibo traditions. Unachukwu though being a mimic man was respected by his natives as he was a matter of pride for his kinsmen. Ezeulu also admired Unachukwu and he wanted Oduche to follow Unachukwu. Oduche was most influenced by a West Indian missionary called Blackett. "It was said that this man although black had more knowledge than white men. Oduche thought that if he could get one-tenth of Blackett's knowledge he would be a great man in Umuaro" (48).

Moses Unachukwu is the "first and most famous convert in Umuaro" (47). He belongs to the very first group of the first phase of colonial imitation. He acts as a medium of communication between the natives and the white men. Unachukwu was a carpenter. He learnt the trade under the white missionaries. In his youth the British conscripted him to carry the loads of the soldiers who were sent to Abame. "What Unachukwu saw during that punitive expedition taught him that the white man was not a thing of fun" (47). The destruction of Abame by the white men taught Unachukwu of their power and mission. He understood that in near future Umuaro will also come under the White man's government. In fact, he perceived the inevitability to become a part of white man's system. After his release he did not went back to Umuaro. He chose to go to Onitsha where he became a houseboy to a carpenter-missionary. He managed to speak English and learnt carpentry. After ten years he returned to Umuaro with the group of missionaries who succeeded after two previous failures in planting the "new faith" among the natives. The success of the third missionary was largely due to presence of Unachukwu. Being a fated mimic man, he must have helped the missionaries in communicating with the "heathens" as he knows both Ibo and English. "He saw his sojourn in Onitsha as a parallel to that of the Moses of the Old Testament in Egypt" (47).

As he was the only carpenter in the neighbourhood Unachukwu almost single-handed built the new church in Umuaro. He enjoyed the status of a mimic man and had influence and dominance over the natives. He was envied by Ezeulu mainly because he belonged to Umuachala, but Ezeulu wanted his son to be like him. It is Unachukwu's power and status that attracted Ezeulu. The catechist Mr. Molokwu, who also belongs to the first group of the first phase of mimic men, consulted Unachukwu in whatever he did. But $\mathrm{Mr}$. Goodcountry who belongs to a different part of Nigeria does not like Unachukwu mainly for his ambivalence.

During the construction of new road Unachukwu turns as a mediator between the native workers that include Ezeulu's son Obika and the white men under Mr. White. His role as a negotiator increases his reputation to unprecedented heights. During the fight between Mr. Wright and Obika Unachukwu throws himself between the two. As a mimic man his position is thus between the colonized and the colonizer. According to Bhabha he belongs to the category of the "other." But like Obi Okonkwo's father or James Ikedi he is not hard-hearted towards his kinsmen.But he as a mimic man, could not resist but propagate the fear of white man among the natives. He screams at Obika when he attacks Mr. Wright: "Are you mad to attack a white man?" (82) He always instilled fear among the natives and thus helped the British in establishing their supremacy. He used to tell the natives that the white man would reply the native's arrogance by taking all their leaders to prison at Okperi. He tells the youths assembled for road construction that there is no escape from the white man.

He [white man] come. When suffering knocks at your door and you say there is no seat left for him, he tells you not to worry because he has brought his own stool. The Whiteman is like that. Before any one of you here was old enough to tip a cloth between the legs I saw with my own eyes what the white man did to Abame. The I know there was no escape. As daylight chases away darkness so will the white man drive away all our customs. I know that as I say it now it passes by our ears, but it will happen. The white man has power which comes from the true God and it burns like fire. This is the god about whom we preach every eighth day..." (84-85) 
Unachukwu is well aware of the white man and their policies. He knew that the "white man, the new religion, the soldiers, the new road- they are all part of the same thing" (85).

Moses Unachukwu was directly forced by the white man to follow their life style. Unachukwu was convinced of the white man's power is it nothing but fear that compelled him to convert to the new religion. He envisioned the future and secured his place in the colonisation process. As a true "mimic man" he shows a greater degree of ambivalence. He is strongly influenced by his native Chief Priest of Idemili. He bluntly speaks against Mr. Goodcountry who calls the converts to kill the royal python. His great knowledge of the Bible also gives him confidence as points out that "neither the Bible nor the catechism asked converts to kill the python, a beast full of ill omen" (48). He tells the converts a story that proclaims the importance of the sacred-python. He tells that Umuaro actually was a union of seven villages. But the seventh village was destroyed as a result of the wrath of the God when the six brothers killed and cooked the meat of a royal python. After this incident the other villagers declared it as an abomination to kill the sacred python. Unachukwu convinces the coverts that killing a sacred-python will bring destruction. It is this same Unachukwu that preaches the power of the new religion. $\mathrm{He}$ is a firm believer of Christianity and considers Jesus as the real God and at the same time he values his native religion too. This simply reveals the ambivalence of Unachukwu. Mr. Goodcountry prefers to ignore Unachukwu for this ambivalence. Mr. Goodcountry scorns him: "You [Unachukwu] say you are the first Christian in Umuaro, you partake of the Holy Meal; and yet whenever you open your mouth nothing but heathen filth pours out" (49).

$\mathrm{He}$ is not exactly a "menace" of Bhabha's theory, but to an extent he is the only voice of anticolonial resistance present in Arrow of God. He invades the dominance of Mr. Goodcountry who is also a mimic man, but one without ambivalence.

I have been to the fountainhead of this new religion and seen with my own eyes the white people who brought it. So I want to tell you now that I will not be led astray by outsiders who choose to weep louder than the owners of the corpse. You are not the first teacher I have seen; you are not the second; you are not the third. If you are wise you will face the work they sent you to do here and take your hand off the python. You can say that I told you so. Nobody here has complained you that the python has ever blocked his way as he came to church... (50)
The speech is not only a warning against $\mathrm{Mr}$. Goodcountry, but one against the Church. He does not want the church to intrude in to the native religion and its customs. Though we have another character called John Nwodika who is also ambivalent mimic man like Unachukwu, Nwodika offers no resistance.

John Nwodika was a steward to Captain Winterbottom. He belongs to the first group of mimic man. He was introduced into the household of the white man by another mimic man named Ekemezie. Nwodika was only a boy when Ekemezie lured him with his word: “...a man of sense does not go on hunting little bush rodents when his age mates are after big game...He said that the race for white man's money would not wait till tomorrow or till we were ready to join; if the rat could not run fast enough it must make way for the tortoise" (169). At first the white man put him to weed his compound. Then Nwodika is been asked to work inside the home of white man as his handiwork appeared good. "He asked me my name and I told him my name was Nwabueze; but he could not call it so he said he would call me Johnu" (170). His duty was just to put things in order in the white man's house. According to Nwodika: “...the white man is not like us; if he puts this plate here he will be angry if you have it there" (170).He does not enjoy a high status like Unachukwu. But he himself consider him as above the ordinary natives who condemns him for "licking plates in the white man's kitchen" (162) and tries to convince his kinsmen that he is not actually a cook. For Nwodika "...colonial mimicry is the desire for a reformed, recognizable Other..." (126)

Nwodika is told to accompany the policeman. But he doesn't want to go, especially when he learns they plan to arrest Ezeulu. So he makes alternative plans and when the policemen arrive, they discover that he is ill. He tells them anybody in Umunneora can tell them where Ezeulu's house is. Like Unachukwu he too admires the native traditions. Nwodika is apparently ambivalent when he attributes the cause of Winterbottom's illness to Ezeulu's magical power. His conversation with Ezeulu shows he compassionate towards the natives. He admires both Ezeulu and Winterbottom. He is sad about his fate and is aware about the fact that he does not belong to the natives or the white men's system. The predicament of Nwodika reveals the absurdity of being a mimic man. Mimicry is absolutely mockery in his case. He says of his absurd situation: "Sometimes I feel shame when others ask me where I come from. We have no share in the market; we have no share in white man's office; we have no share anywhere" (170). This situation is almost alike for all mimic man of his generation.

Unachukwu and Nwodika became mimic men as they desired to elevate their status. They are colonial 
subjects "of a difference that is almost the same, but not quite true" (126). Though they are "authorized versions" produced by the colonizer they are only capable of having an existence of "partial presence." Bhabha defines this "partial" as both "incomplete" and "virtual." The colonizers' tactics to avoid menace best represented by Charles Grant who introduced Christianity in a way that will create only a "partial reform" is present in every aspect of the production of mimic man. The colonizers knew "that "partial reform" will produce an empty form of "the imitation" of the English manners which will induce them [colonial subjects] to remain under our protection" (127).

The story of white man who destroyed Abame worried all the Umuofians. They were afraid of them and at the same time very curious. It took no time for the white man to stamp their place in Umuofia.

The missionaries had come to Umuofia. They had built their church their, won a handful of converts...None of his converts was a man whose word was heeded in the assembly of the people. None of them was a man of title. They were mostly the kind of people that were called efulefu, worthless, empty men... Cheilo, the priestess of Agbala, called the converts the excrement of the clan, and the new faith was a mad dog that had come to eat it up (135).

Nwoye was one among those converts. He left his father to join the school set by the missionary "to teach the young Christians to read and write... He would return later to his mother and his brothers and sisters and convert them to the new faith" (144). The white men were careful in establishing their superiority. They made the new converts to obey the rules of the new religion and infused in them a feeling of inferiority complex. At the end of the novel we see the white man using force to obey the natives.

By the time of Ezeulu the white men have already established their government. They began to interfere in the affairs of the village and used force to settle disputes. The number of converts has increased and mimic men began to enjoy a dominant status among the natives. The power enjoyed by men like Unachukwu or James Ikedi attracted other natives to Christianity. Catechists like Mr. Goodcountry preached: "If we are Christians, we must be ready to fight for the faith" (47). Most of the mimic men like Ikedi were both powerful and corrupt. Ikedi for example is an adamant follower of Christianity. He is one among the first converts to receive missionary education and is highly influenced by the British model of Government. "He had set up an illegal court and a private prison. He took any woman who caught his fancy without paying the customary bride- price" (57). He exploited the villagers by levying illegal tax. $\mathrm{He}$ is an example of the negative side of mimicry. He was just mimicking the real-great-colonial exploiters. "The latest thing he did was to get his people to make him an obior king, so that he was now called His Highness Ikedi the First, Obi of Okperi. This among a people who abominated kings! This was what British administration was doing among the Ibos, making a dozen of mushroom kings grow where there was none before" (58). Achebe's "mushroom kings" is another name for the mimic man. Winterbottom is aware about the corrupt deeds of these "mushroom kings" that is why he opt to choose a native leader like Ezeulu as the warrant chief of Umuaro. From a post-colonial perspective Winterbottom's action is a deliberate attempt to avoid "menace". When Winterbottom says "We must not destroy the African atmosphere, the African mind, the whole foundation of his race..." (56) $\mathrm{He}$ is revealing his fear that once the mimic men are given more power they will be enough to overthrow the white officials at the top.

Though most of the white officials shows aversion to the mimic men, there are instance when they prove to be useful also. Mr. Wright at first distrust Unachukwu "as he distrusted all "uppity natives" but soon he found him very useful and was now even considering giving him some little reward..." (77)

The white man's attitude towards the natives was very bad. They consider the natives as uncivilised and force them to accept their own inferiority. For Winterbottom the natives are "great liars." His attitude towards the mimic men reflect in his words about Ikedi: "The man was a complete nonentity until we crowned him, and now he carries on as though he had been nothing else all his life. It's the same with Court Clerks and even messengers. They all manage to turn themselves into little tyrants over their own people. It seems to be a trait in the character of the negro" (107). The colonizer for their own purposes created mimic men that includes stewards, interpreters to high officials and ministers. But they do not accept the fact that the corruption and other negatives of the mimic man is only but an imitation of the ways of white man itself. From these words of Winterbottom, it is clear that the white men are unaware of their own tyrannical manners. At the same time, they are careful in avoiding menaces. The letter from the Secretary of Native Affairs on Indirect Rule in Eastern Nigeria asks Winterbottom to handle the matter of Ezeulu and other mimic men "with tact so that the Administration did not confuse the minds of the natives or create the impression of indecision or lack of direction as such would do untold harm" (181).

As we see in the case of Unachukwu mimic men are also careful in establishing the dominance. The first 
group of mimic men who were mostly interpreters, played a vital part in luring the natives to Christianity. We can also say that the mimic men are so moulded to lessen the toil of the colonizers.

The delay to the New Yam Feast was both due to the detention of Ezeulu by the white man. The people knew that the delay was all a work of the white man but the white government was very tactical in all their action. They see the plight of the villagers and their rage against Ezeulu due to the delay of declaring the New Yam Feast as a suitable opportunity to directly intrude into the native affairs.

Now Mr. Goodcountry saw in the present crisis over the New Yam Feast an opportunity for fruitful intervention. He had planned his church's harvest service for the second Sunday in November the proceeds from which would go into the fund for building a place of worship more worthy of God and of Umuaro. His plan was quite simple. The New Yam Festival was the attempt of the misguided heathen to show the gratitude to God, the giver of all good things. This was God's hour to save them from their error which was now threatening to ruin them. They must be told that if they made their thank-offering to God they could harvest their crops without fear of Ulu (215).

The new converts and Unachukwu considered this plot as a way to help their "heathen brethren." So with the involvement of new converts "the news spread that anyone who did not want to wait and see all his harvest ruined could take his offering to the god of the Christians who claimed to have power of protection from the anger of Ulu. Such a story at other times might have been treated with laughter. But there was no more laughter left in the people" (216). As the novel ends we see Christianity overthrowing the native religion: "Thereafter any yam harvested in his fields was harvested in the name of the son" (230).

\section{CONCLUSION}

The white men, as we see in the African Trilogy, were successful in establishing themselves as the civilised, educated, reformed and disciplined category. By using their religion and education as tools, they forced the colonized to accept their own inferiority. The colonized are considered to be barbaric, ignorant and primitive. The colonized too accepts their inferiority. As their culture is destroyed by the colonizers they have no option left but to follow the white man's culture and norms. To gain an identity or a social status, the colonized start imitating the colonizer. Thus 'mimic man' is an identity attributed by the white man to the colonized.

But the real identity of the person is destroyed or suppressed as he becomes a mimic man. This leaves the person to an ambivalent and confused state. Thus "the discourse of mimicry is constructed around an ambivalence..." (126). In African Trilogy we see how mimic men like Unachukwu and Nwodika are initiated into colonial mimicry. They desired for a better social status and as the native culture and religion is degrading they had no other options left. But they both show ambivalence due to the conflict between the two cultures.

Apart from gaining a superior status there are factors like 'fear' or 'inevitability' that encourages a native to become a mimic man. It is the fear that leads Unachukwu and Ezeulu to admire the white man.

Mimicry problematizes racial identity and cultural priority due to the hybridization of the culture. As a result, "the national is no longer naturalizable" (128) because everything is hybridized. Mimicry mixes cultures and hence makes everything complex. In other words, mimicry is a complex phenomenon, which not only affect human behaviour but also a person's attitude (racial) and temperament. That is why we see mimic man like Sam Okeli, John Ikedi and Isaac Okonkwo forget their racial identity, despises their native religion and act like westerners.

\section{REFERENCES}

[1] Achebe, Chinua. Arrow of God. Oxford: Heinemann Publishers, 1989. Print.

[2] ---. No Longer at Ease. London: Penguin Books, 2010. Print.

[3] ---. "The Novelist as a Teacher." Hopes and Impediments: Selected Essays. London: Heinemann, 1988. Print.

[4] ---. Things Fall Apart. London: Penguin Books, 2010. Print.

[5] Ashcroft Bill, Gareth Griffiths and Helen Tiffin, eds.Post-Colonial Studies:The Key Concepts. New York: Routledge, 2007. Print.

[6] Bhabha, Homi K. "Of Mimicry and Man: The Ambivalence of Colonial Discourse." Discipleship: A Special Issue on Psychoanalysis. Cambridge: MIT Press, 1984. 125-133. Print.

[7] ---. The Location of Culture. New York: Routledge, 1994. Print. 